\title{
Social Networking Sites and Sexual Behaviour of Students of Tertiary Institutions in Kogi State, Nigeria
}

\author{
Asogwa. Chika Euphemia ${ }^{1}$, Ojih. Success Emmanuel Unekwu ${ }^{2}$ and Onoja. Ibe Ben ${ }^{3}$ \\ ${ }^{1,2}$ Department of Mass Communication, Federal University Oye-Ekiti, Nigeria. \\ ${ }^{3}$ Department of Mass Communication, Kogi State University, Anyigba-Nigeria
}

\begin{abstract}
This study was conceived to examine social networking sites and sexual behaviour of students of tertiary institutions in Kogi State. The study employed survey research method and relied on questionnaire and interview guide as instruments for the collection of primary data. The data were quantitatively and qualitatively analyzed using tables showing frequencies and simple percentages. Multi-stage sampling technique was used to sample the 384 respondents from the selected tertiary institutions. Anchored on the Uses and gratifications theory, the study found; that social networking sites contribute to student's sexual behaviour and that they are exposed to sexual contents of sorts. The study concludes that SNSs utilization may promote sex education and pleasure, but indiscriminate sexual activities are also promoted. The study recommends that the use of SNSs should be regulated among students, and stressed the need for awareness and re-orientation of students on the safest way of using the social platforms.
\end{abstract}

Keywords: Social Networking Sites, Sexual Behaviour, Students, Sexuality, Nigeria.

\section{Introduction/Problem Statement}

Earlier studies have demonstrated that Social Networking Sites are widely embraced by the younger generation, variously labelled 'Generation Y (Digital Natives and the Net Generation),' (Oblinger \& Oblinger 2005, p. 2). This, McLoughlin \& Burgess (n.d) noted, could be as a result of the fact that "SNSs break down barriers at different levels, such as private and public space, learning spaces and social spaces, and informal and formal communication modes'. Youths face social risks on these sites just as they do in any other public space in which people congregate. For instance, Dowdell, Burgess \& Flores (2011), observed that "social networking sites, aided by technology-induced anonymity have popularized sex". This buttresses CyberAtlas (2001) assertion as cited in Brown (2002) that the "social media have increased dramatically the availability of sexually explicit/implicit content".

Sexual talk and displays are increasingly frequent and explicit in this mediated world so much so that people are using the internet to form friendships and romances and to initiate inordinate affairs (Katherine, 2006 as cited in Longe, Chiemeke, Onifade \& Balogun 2007, p. 196). Therefore, 'sex' minded people are smarting on opportunities provided by SNSs to lure, solicit, and sexually exploit people. As such, "sexuality behaviour among students in Nigeria and sub-Saharan Africa is seriously going through transformation from what it used to be in the past", (Ojo \& Fasuba, 2005, p. 112).

The prevalence of negative behaviours among students of tertiary institutions in Nigeria has witnessed a steady rise over the past few years, as people take advantage of the anonymity in cyberspace to exploit themselves/their victims. Although, research on young people's use of social networking sites is beginning to accumulate, questions still remained yet unanswered regarding what exactly students of tertiary institutions in Kogi state, Nigeria are exposed to on these sites and its influence on their sexual behaviours. 
Therefore, this study, which is limited to tertiary institutions in Kogi State, Nigeria, is an attempt to bridge the research gap identified above using an empirical method. To this end, the study is set out to achieve the following objectives: To ascertain the aspects of sexuality portrayed on social networking sites among students of tertiary institutions in Kogi State and to find out the influence of sexual contents on SNSs on the sexual behaviour of students of tertiary institutions in Kogi State.

\section{Review of Literature}

Social networking is as old as humans have been around. Just as in nearly every other species, humans have an instinctual need to be communicated with, and share thoughts, ideas, and feelings about their daily lives. But according to Safko (2010, p. 5) "only the tools with which we communicate have changed over the Millennia". Social media make it possible to share such information like photos, videos, audio files, and comments. These sites seem to be gaining such high popularity among users. This point was aptly emphasized by Stefanone, Lackaff, and Rosen (2010) when they affirmed that explosion in popularity of social networking sites (SNSs) represents one of the fastest uptakes of communication technology since the web was developed in the early 1990s.

The popularity and prevalence of sexual immorality among youths, especially students at various levels of education in Nigeria today is generally alarming. This, sexual decadence according to Olufemi \& Olu (2012, p. 361) "has grown to a level that creates fear and tension in the heart of anyone who has concern for the future of Nigeria as a nation and the teeming youths that populates it". They add further that "One of the outstanding remarkable virtues of a good society should be sexual purity which has received little or no attention from the society today". But instead, in the words of Dotonu, (2011), "majority of the students have become major in sexual immorality but minor in academics".

Globally, young people, powered by the instrumentality of Social Networking Sites (SNSs) that enables all manner of infectious interactions, now embrace modern principles of living that largely promotes promiscuity and perversions of sorts, thereby compromising their core cultural ideals that promote sexual purity without looking back. In an attempt to localize this effect, Ajayi (2006) and Adebule (2012) were quick to add that "the incidence of sexual immorality among Nigerian youths has become sporadic'. This they attributed to "the negative influence of mass media/internet especially the pornographic films and videos often freely displayed on these sites". These have propagated all forms of 'unfamiliar' and debasing sex cultures among this generation of the digital natives, where even worse, adults are no pushovers!

In the past few years, cases of assorted sexual crimes had received greater attention from the mass media. There are cases of immorality that are in the news like; "teacher sleeping with/raping his/her student", "pastor raping a church member", "security man sleeping with his master's daughter or wife", "father sleeping with his daughter", "teenagers sleeping with themselves", "students gang-raping fellow students, etc. The society is overcharged with sexual immorality and men, women, the young and old are helplessly falling victim. Little wonder why Olufemi et'al $(2012$, p. 362) put the blame on the society because "it has completely failed to address the issue of immorality among its youth, which is escalating everyday".

Most forms of sexual deviances are accompanied by a number of other psychological disorders. Today, psychologists generally refer to non-traditional sexual behaviours as sexual deviation especially where the specific object of arousal is unusual (Lee, 2011, p. 6).

\section{Theoretical leaning: Uses and Gratifications Theory}

In recent years, a number of researchers have called for the application of uses and gratifications theory in the context of new media, such as the internet and mobile phones (Grant 2005, p. 112; Grant \& O'Donohoe 2007, p. 225). This theory rather than place emphasis on the media puts more emphasis on the consumers whose choices of the media to use is determined by the gratifications they derive from it. The power of choice of 
exposure lies with the user especially in this age of multiplicity of voices with every media of communication/interaction offering something that is somewhat unique.

Uses and gratifications theory is very relevant to this work because, in addition to the above reasons; it offers explanations to suggest that students use social networking sites for varying reasons which may also include conscious exposure to sexual contents or even the exchange of same. In other words, users select media based on how well each one helps them meet specific needs or goals.

\section{Methodology}

Survey research method was employed for this study. Using questionnaire and interview as instruments of primary data collection, the researcher relied on Fisher's sample size determination formula as cited in Ibrahim (2009) to arrive at a sample of 384 from a total population of 23,474. To ensure a close representation of the population characteristics, multi-stage (proportionate quota, purposive and simple random) sampling technique was adopted.

Purposive sampling was in the first place used to determine the schools used for the study based on their year of establishment and population density. Based on these factors, Kogi State University, Anyigba, Federal Polytechnic, Idah, and Federal College of Education, Okene all of Kogi State, Nigeria were selected as study areas.

Because of the variation in the population proportion of the three selected tertiary institutions in Kogi state, proportionate quota sampling technique was used for the distribution of the questionnaire among the institutions and selected departments. As a result therefore, 222 respondents were taken from KSU Anyigba, 99 respondents from FPI Idah and 63 respondents from FCE Okene.

The proportion of the instruments that went to Kogi State University was distributed to four faculties out of six which was selected using simple random sampling. Also, the selected faculties automatically produced the levels that were sampled in the order in which they emerged. That is, the first faculty picked through balloting produced 100 level; and the others followed in similar fashion. The researchers decided to use only four faculties to avoid complexities that would have arisen in the process of selecting the levels adopted for the study. However, the four faculties that were picked were still subjected to another round of balloting to determine the one department to represent each of the faculties.

The same process was repeated at the Federal Polytechnic, Idah and the Federal College of Education, Okene. However, the four major schools in FPI were purposively selected (the fifth school, General Studies, was exempted because all the members of the selected four schools were sub-sets of the school). Nonetheless, while only three schools were randomly selected in FCE, Okene, the first school chosen produced NCE I, followed by the second and the third, meaning NCE II and III respectively. At the point of the field work, the researcher administered the questionnaire randomly on the departments and respondents that emerged from the process.

On the personal interview, purposive sampling technique was used to ensure that only nine volunteers from the final levels (three interviewees from each of the institutions) were chosen for the interview. This is because of their level of experience which places them in a better position to make informed comments/contributions to the discussion.

Besides, a pilot study was conducted to pre-test the instruments to afford the researcher the opportunity of studying and restructuring some of the items in the instruments that appeared confusing to the respondents/participants. The researcher adopted both qualitative and quantitative methods in presenting and analyzing the data collected from the field. 


\section{Results: Data Presentation and Analysis (Quantitative Approach)}

Out of the 384 respondents sampled and issued copies of the questionnaire, 376 returned their copies, yielding $97.9 \%$ return rate while 8 copies $(2.1 \%)$ were not returned or returned invalid. As such, the data is presented in the tables below based on the valid copies of the questionnaire returned.

TABLE 1: Respondents Demography $(\mathrm{n}=376)$

\begin{tabular}{|c|c|c|c|c|c|c|c|c|}
\hline \multirow{2}{*}{$\begin{array}{l}\text { Institutions } \\
\text { Items }\end{array}$} & \multicolumn{2}{|c|}{ KSU (n=218) } & \multicolumn{2}{|c|}{ FCE $(n=62)$} & \multicolumn{2}{|c|}{ FPI $(n=96)$} & \multicolumn{2}{|c|}{ Sub Total } \\
\hline & $\mathrm{F}$ & $\%$ & $\mathrm{~F}$ & $\%$ & $\mathrm{~F}$ & $\%$ & $\mathrm{~F}$ & $\%$ \\
\hline \multicolumn{9}{|l|}{ Sex } \\
\hline Male & 101 & 46 & 34 & 55 & 44 & 46 & 179 & 48 \\
\hline Female & 117 & 54 & 28 & 45 & 52 & 54 & 197 & 52 \\
\hline Total & 218 & 100 & 62 & 100 & 96 & 100 & 376 & 100 \\
\hline \multicolumn{9}{|l|}{ Age } \\
\hline Below 20 & 84 & 39 & 17 & 27 & 22 & 23 & 123 & 33 \\
\hline $20-25$ & 111 & 50 & 41 & 66 & 64 & 67 & 216 & 57 \\
\hline $26-30$ & 21 & 10 & 4 & 7 & 7 & 7 & 32 & 9 \\
\hline $31-35$ & 2 & 1 & 0 & 0 & 3 & 3 & 5 & 1 \\
\hline $36 \&$ above & 0 & 0 & 0 & 0 & 0 & 0 & 0 & 0 \\
\hline Total & 218 & 100 & 62 & 100 & 96 & 100 & 376 & 100 \\
\hline \multicolumn{9}{|l|}{$\begin{array}{l}\text { Educational } \\
\text { Programme }\end{array}$} \\
\hline Degree & 218 & 58 & 0 & 0 & 0 & 0 & 222 & 58 \\
\hline $\mathrm{ND} / \mathrm{HND}$ & 0 & 0 & 0 & 0 & 96 & 26 & 96 & 26 \\
\hline $\mathrm{NCE}$ & 0 & 0 & 62 & 16 & 0 & 0 & 62 & 16 \\
\hline Total & 218 & 58 & 62 & 16 & 96 & 26 & 376 & 100 \\
\hline
\end{tabular}

Source: Field Work, 2014

Table one on the item of sex of respondents shows that 179 representing $48 \%$ were males while a slight majority of the respondents, 197 representing 52\% were females. The data in item two indicated the age category of the respondents and reveal that majority of the respondents, meaning 216 (57\%), fall within the 20-25 years age bracket followed by those below 20 years, 123 (33\%); 26-30 years had 32 (9\%); and 31-35 years, 5 (1\%); while none of the respondent is 36 years old and above. Specifically, respondents within 20-25 years age bracket dominated the result from the three selected schools. The last item on table 1 (Educational programme in view) shows that 218 respondents representing 58\% are degree students; 96 representing $26 \%$ are ND/HND students while 62 representing $16 \%$ are pursuing NCE. The variation is due to the differences in the sample size drawn from each of the schools based on their population contributed to the total population.

TABLE 2: Respondent's Frequency of visit to SNSs ( $\mathrm{n}=376$ )

\begin{tabular}{|l|l|l|l|l|l|l|l|l|}
\hline Institutions & \multicolumn{2}{|l|}{ KSU $(\mathrm{n}=218)$} & FCE $(\mathrm{n}=62)$ & \multicolumn{2}{l|}{ FPI (n=96) } & Sub Total \\
\hline Response & F & $\%$ & F & $\%$ & F & $\%$ & F & $\%$ \\
\hline $\begin{array}{l}\text { Very } \\
\text { regularly }\end{array}$ & 53 & 24 & 11 & 18 & 15 & 16 & 79 & 21 \\
\hline Regularly & 103 & 48 & 12 & 19 & 26 & 27 & 141 & 37 \\
\hline Not regularly & 48 & 22 & 30 & 48 & 37 & 38 & 115 & 31 \\
\hline Hardly & 14 & 6 & 9 & 15 & 18 & 19 & 41 & 11 \\
\hline Never & 0 & 0 & 0 & 0 & 0 & 0 & 0 & 0 \\
\hline Total & 218 & 100 & 62 & 100 & 96 & 100 & 376 & 100 \\
\hline
\end{tabular}

Source: Field Work, 2014

The table shows that all of the 376 respondents said they visited the sites frequently but at different levels. While a majority of them, 37\% (141) visits the sites regularly; 31\% (115) do not use it regularly; 27\% (79) use same very regularly, only $11 \%$ (41) hardly use it and none went for Never meaning all of them use at least, a social networking site. 
TABLE 3: Sexual Materials Often Portrayed/Exchanged on SNSs ( $\mathrm{n}=376)$

\begin{tabular}{|l|l|l|l|l|l|l|l|l|}
\hline Institutions & KSU $(\mathrm{n}=218)$ & FCE $(\mathrm{n}=62)$ & \multicolumn{2}{l|}{ FPI $(\mathrm{n}=96)$} & \multicolumn{2}{l|}{ Sub Total } \\
\hline Response & $\mathrm{F}$ & $\%$ & $\mathrm{~F}$ & $\%$ & $\mathrm{~F}$ & $\%$ & F & $\%$ \\
\hline Nude/Semi Nude Pictures & 61 & 28 & 18 & 29 & 31 & 32 & 110 \\
\hline Pornographic Scenes & 28 & 13 & 10 & 16 & 17 & 18 & 55 \\
\hline Pornographic Sites & 42 & 19 & 6 & 10 & 16 & 17 & 64 & 15 \\
\hline Sexually Suggestive Language & 79 & 36 & 28 & 45 & 29 & 30 & 136 & 36 \\
\hline Others & 8 & 4 & 0 & 0 & 3 & 3 & 11 \\
\hline Total & 218 & 100 & 62 & 100 & 96 & 100 & 376 & 3 \\
\hline
\end{tabular}

Source: Field Work, 2014

In table 4 above, 55\% (207) of the respondents agreed (Yes) that sex related materials exchanged online affects students behaviour offline. 36\% (134) said it does not (No); while 9\% (35) said they are Not Sure if it does.

TABLE 5: Respondents Description (open ended question) of the Positive influence of Romantic/Sex Related Materials Exchanged on SNS on Students' behaviours $(n=239)$

\begin{tabular}{|c|c|c|c|c|c|}
\hline \multirow{3}{*}{$\begin{array}{l}\text { Areas of Positive } \\
\text { Influence }\end{array}$} & \multirow[t]{3}{*}{ Examples of the Positive influence in respective Areas } & \multicolumn{3}{|c|}{ Institutions } & \multirow[t]{3}{*}{ Tota } \\
\hline & & $\begin{array}{l}\mathrm{KSU} \\
\mathrm{n}=119\end{array}$ & $\begin{array}{l}\mathrm{FCE} \\
\mathrm{n}=44\end{array}$ & $\begin{array}{l}\text { FPI } \\
\mathrm{n}=76\end{array}$ & \\
\hline & & Freq. & Freq. & Freq. & \\
\hline Relationship & $\begin{array}{l}\text { 1. Opportunity to get a spouse } \\
\text { 2. Making new friends } \\
\text { 3. To maintain friends } \\
\text { 4. Helps to make relationship stronger } \\
\text { 5.Makes getting a relationship (dating) easier \& faster }\end{array}$ & $\begin{array}{l}25 \\
43 \\
28 \\
69 \\
36\end{array}$ & $\begin{array}{l}18 \\
28 \\
31 \\
22 \\
28\end{array}$ & $\begin{array}{l}22 \\
37 \\
39 \\
31 \\
44\end{array}$ & $\begin{array}{l}65 \\
108 \\
98 \\
122 \\
108\end{array}$ \\
\hline Sex Education & $\begin{array}{l}\text { 1. Teaches on the specific effects of sex } \\
\text { 2.Contributes to making one a sex expert } \\
\text { 3.Teaches romance \& how to be romantic } \\
\text { 4.For information on vital sex issues } \\
\text { 5.Fertile ground to experience sex }\end{array}$ & $\begin{array}{l}11 \\
16 \\
21 \\
49 \\
13\end{array}$ & $\begin{array}{l}9 \\
4 \\
19 \\
21 \\
0\end{array}$ & $\begin{array}{l}21 \\
12 \\
18 \\
31 \\
6\end{array}$ & $\begin{array}{l}41 \\
32 \\
58 \\
101 \\
19 \\
\end{array}$ \\
\hline Freedom & $\begin{array}{l}\text { 1.Avenue to express emotional feelings } \\
\text { 2.Uninhibited access and freedom to belong }\end{array}$ & $\begin{array}{l}37 \\
11\end{array}$ & $\begin{array}{l}12 \\
9\end{array}$ & $\begin{array}{l}12 \\
0\end{array}$ & $\begin{array}{l}61 \\
20\end{array}$ \\
\hline Pleasure & $\begin{array}{l}\text { 1. Creates active sex life } \\
\text { 2.To catch fun } \\
\text { 3.For relaxation \& enjoyment }\end{array}$ & $\begin{array}{l}8 \\
16 \\
18\end{array}$ & $\begin{array}{l}0 \\
5 \\
0\end{array}$ & $\begin{array}{l}2 \\
14 \\
2\end{array}$ & $\begin{array}{l}10 \\
35 \\
20\end{array}$ \\
\hline Leisure & 1. To pass away time & 4 & 6 & 0 & 10 \\
\hline None & 1. It has no positive effect & 13 & 2 & 6 & 21 \\
\hline
\end{tabular}

\section{Source: Field Work, 2014}

The responses to this open-ended question were first of all coded into various themes and sub- themes based on their similarity to allow for easy collation and analysis. The five major themes and their sub- themes as raised by the respondents and coded by the researcher is as seen below. The first major theme identified by the respondents is Relationship which was coded $\mathrm{R}$ and the five sub- themes suggesting relationship were coded as $\mathrm{R}_{1}, \mathrm{R}_{2}, \mathrm{R}_{3}, \mathrm{R}_{4}$, and $\mathrm{R}_{5}$; others are Sex Education ( $\mathrm{S}$ ) and the points that fell under it came as $\mathrm{S}_{1}, \mathrm{~S}_{2}, \mathrm{~S}_{3}, \mathrm{~S}_{4}$, and $\mathrm{S}_{5}$; Freedom $(\mathrm{F})$ and its points are $\mathrm{F}_{1}$ and $\mathrm{F}_{2}$; Pleasure $(\mathrm{P})$ and the sub-themes are $\mathrm{P}_{1}, \mathrm{P}_{2}$ and $\mathrm{P}_{3}$. Leisure $(\mathrm{L})$ was coded as $\mathrm{L}_{1}$ and None $(\mathrm{N})$ with $\mathrm{N}_{1}$. It should also be noted that not all the respondents answered the open-ended question. A total of 137 of the respondents did not fill this part of the questionnaire.

As shown in the table, respondents have somewhat common and different opinions about the positive effects of SNSs on their sexual behaviour. According to the results, most of the respondents keyed-in to the positive effect on Relationship grounds. A total of 65 participants opined that Relationship wise, it affords people the opportunity to get their life partners; a second highest number of respondents with 108 went for making of new friends; 98, believes it helps to maintain already existing friends while the largest group of respondents, 135, strongly affirm that it makes dating a lot easier and faster.

Another issue identified by the respondents is in the aspect of Sex Education. A good number of the respondents (101) believe that one of the positive effects of exchanging sexual or sexually related materials on SNSs on students' sexual behaviour is that, it provides information on vital sex issues while 58 respondents 
suggested that one learns romance and how to be romantic from SNSs. 41 of the respondents say it teaches them on specific effects of sex but 32 affirm it also contributes to making one a sex expert giving them different insights into some "current unique sex styles available". According to 19 of the respondents, SNSs provide a more special platform to "experience sex in unrestricted and uncommon ways". Meanwhile, no respondent in FCE said it is a fertile ground to experience sex.

Also, issues revolving around Freedom formed part of their responses on the positive effects of exchanging sexual/romantic contents on the SNSs. However, responses that fitted into this category were two. A higher number of 61 respondents noted that it creates an unrivaled, 'unrestrictable' and a more "express opportunity to express emotional feelings of sorts" like love, sex, relationships/marital issues and/or sharing experiences which may include nude/semi nude pictures of self or even that of others, pornographic sites, etc. Similarly, 20 of them opined that it gives 'uninhibitable' access to "all colours of people you can think of whether white, black or yellow" and also the accompanying freedom to "belong to any group or ideological wave and be part of the inthing". The "freedom" to communicating their repressed sexual/sexually related desires/feelings/habits and similar ensuing activities that is in some ways curtailed in the off-line society in most cases, and even in some cultures perceived to be wrong and as such frowned at in its entirety, is what the SNSs offers them on a platter of gold. Meanwhile, there was no respondent in FPI that noted the freedom to belong as one of the positive effects of sharing sex related materials on SNSs.

Deriving Pleasure is another theme that emerged out of the issues raised as positive effects. Here, 10 of the respondents said something suggesting that it creates an active sex life meaning frequent indulgence in sex/sex related activities. 35 noted catching fun as one of the positive effects while 20 believes it is good for relaxation and enjoyment. It is clear from the table that no respondent in FCE referenced either active sex life or relaxation and enjoyment as parts of the positive effects they highlighted.

The remaining theme- Leisure was identified by 10 respondents in the form of whiling away time, even though it is observable that no respondent in FPI mentioned it; and 21 respondents from the three schools said it has no positive effect at all.

TABLE 6: Respondents Description (open ended question) of the Negative influence of Romantic/sex related materials exchanged on SNSs on students $(\mathrm{n}=308)$

\begin{tabular}{|c|c|c|c|c|c|}
\hline \multirow{3}{*}{$\begin{array}{l}\text { Items on Negative } \\
\text { Influence }\end{array}$} & \multirow[t]{3}{*}{ Examples of the Negative influence in the Areas } & \multicolumn{3}{|c|}{ Institutions } & \multirow[t]{3}{*}{ Total } \\
\hline & & $\begin{array}{l}\mathrm{KSU} \\
\mathrm{n}=172\end{array}$ & $\begin{array}{l}\text { FCE } \\
\mathrm{n}=54\end{array}$ & $\begin{array}{l}\text { FPI } \\
\mathrm{n}=82\end{array}$ & \\
\hline & & Freq. & Freq. & Freq. & \\
\hline $\begin{array}{c}\text { Abnormal sexual } \\
\text { behaviour }\end{array}$ & $\begin{array}{l}\text { 1.Created the surge in Homosexuality } \\
\text { 2.It results in unnecessary sexual arousal which often leads to } \\
\text { sexually aggressive acts } \\
\text { 3.It can make one to become sexually addicted } \\
\text { 4.Responsible for the increasing level of Premarital sex } \\
\text { 5.Body Wetting } \\
\text { 6.Prostitution } \\
\text { 7.Brings about Rape } \\
\text { 8.Promotes oral sex } \\
\text { 9.It induces Masturbation }\end{array}$ & $\begin{array}{l}59 \\
32 \\
41 \\
21 \\
0 \\
21 \\
32 \\
14 \\
68\end{array}$ & $\begin{array}{l}30 \\
9 \\
29 \\
14 \\
9 \\
19 \\
21 \\
0 \\
31 \\
\end{array}$ & $\begin{array}{l}35 \\
14 \\
0 \\
32 \\
3 \\
1 \\
34 \\
2 \\
36\end{array}$ & $\begin{array}{l}124 \\
55 \\
70 \\
67 \\
12 \\
31 \\
87 \\
16 \\
135 \\
\end{array}$ \\
\hline $\begin{array}{l}\text { Academic under- } \\
\text { performance }\end{array}$ & $\begin{array}{l}\text { 1.Poor academic performance due to attention diversion } \\
\text { 2.Absence from/lateness to classes } \\
\text { 3.Distraction during classes } \\
\text { 4.Disrupts reading time }\end{array}$ & $\begin{array}{l}37 \\
18 \\
41 \\
0\end{array}$ & $\begin{array}{l}4 \\
0 \\
8 \\
9\end{array}$ & $\begin{array}{l}8 \\
3 \\
16 \\
0\end{array}$ & $\begin{array}{l}49 \\
21 \\
65 \\
9\end{array}$ \\
\hline $\begin{array}{l}\text { Emotional } \\
\text { cheating }\end{array}$ & $\begin{array}{l}\text { 1.Double dating } \\
\text { 2.Increased Peer pressure to imbibe a particular sex life } \\
\text { 3.Creates opportunities for Cross Carpeting in relationships } \\
\text { 4.It also leads to Inter-locking of relationships }\end{array}$ & $\begin{array}{l}43 \\
6 \\
19 \\
11\end{array}$ & $\begin{array}{l}23 \\
0 \\
18 \\
0\end{array}$ & $\begin{array}{l}31 \\
2 \\
6 \\
8\end{array}$ & $\begin{array}{l}97 \\
8 \\
43 \\
19\end{array}$ \\
\hline $\begin{array}{l}\text { Offensive/Poor } \\
\text { Communication }\end{array}$ & $\begin{array}{l}\text { 1.Corrupts language } \\
\text { 2.Ambiguity of expressions }\end{array}$ & $\begin{array}{l}17 \\
12\end{array}$ & $\begin{array}{l}2 \\
7\end{array}$ & $\begin{array}{l}6 \\
0\end{array}$ & $\begin{array}{l}25 \\
19\end{array}$ \\
\hline
\end{tabular}

Source: Field Work, 2014 
Table 6 attempts an open ended question to look at respondents' description of the negative influence of romantic/sex related materials exchanged on SNSs on students' sexual behaviour. Like it is obtainable in table 5 above, in a bid to allow for easy collation and analysis, responses to this open-ended question were also initially all coded into separate themes and sub-themes hinged around their differing responses. The spotted negative themes/sub-themes and their codes include: Abnormal sexual behaviour (A) and the subsumed points came as $\mathrm{A}_{1}$, $\mathrm{A}_{2}, \mathrm{~A}_{3}, \mathrm{~A}_{4}, \mathrm{~A}_{5}, \mathrm{~A}_{6}, \mathrm{~A}_{7}, \mathrm{~A}_{8}$ and $\mathrm{A}_{9}$; Academic under-performance (U) and the points that fell under it were labeled $\mathrm{U}_{1}, \mathrm{U}_{2}, \mathrm{U}_{3}$, and $\mathrm{U}_{4}$; Emotional cheating $(\mathrm{E})$ and its points are $\mathrm{E}_{1}, \mathrm{E}_{2}, \mathrm{E}_{3}$ and $\mathrm{E}_{4}$; Poor Communication $(\mathrm{P})$ and the sub-themes are $\mathrm{P}_{1}$ and $\mathrm{P}_{2}$. It should equally be noted that 68 of the respondents did not fill this part of the questionnaire.

The table reveals that the first theme, Abnormal sexual attitude of sorts is one of the key negative effects adduced by the respondents to describe the negative influence of romantic/sex related materials exchanged on SNSs on students' sexual behaviour. This theme was inferred from the different responses of the respondents. A good number of the respondents (135) independently wrote something suggesting the fact that it could induce masturbation; 124 confirms that it led to the surge in homosexuality; 87 said it brings about rape; while 75 of them agreed that it makes one to become sexually addicted. That it was responsible for the increasing level of pre-marital sex was insinuated by 67 respondents; while 55 say it results in unnecessary sexual arousal which often leads to sexually aggressive acts. Similarly, 31 believe it could also lead to a surge in prostitution; while 16 of them say it promotes oral sex.

It is observable that in all the sampled schools, the act of masturbation was identified by higher number of respondents as negative consequence, followed by its being responsible for the surge in homosexuality. Here, the respondents variously noted the twin negative effects of lesbianism and 'gayism' which could be said to have been on the increase in recent times as one of the core effects arising from 'sharing' on the SNSs. However, no FPI's respondent indicated that it makes them to become sexually addicted but 2 of its respondents alongside 14 of KSU's ascribed the culpability in especially recent rape cases to the exchange of sexual related materials on SNSs. Also, KSU has no respondent that highlighted body wetting just like none of the respondents noted the promotion of oral sex in FCE. Nevertheless, that a particular point was identified by even a respondent shows the possibility of the existence of such negative effects, considering that some of the respondents were not comfortable to answer the question because of its personal nature.

The next issue is academic under-performance. Here, 49 of the respondents observed that it leads to poor academic performance because of its potency to divert attention and energy that should have been channeled towards their studies. Besides, absence from/lateness to classes is one of the negative effects that could arise from the use of SNSs which 21 of the respondents alluded to. 65 of the respondents also said it causes distraction during classes while 9 say it disrupts students' reading time. It must be noted that no respondent in KSU wrote anything that suggests that it disrupts reading time and none in FCE said it leads to absenteeism/lateness to class.

Another theme that emerged is emotional cheating. A good number of respondents (97) implied it leads to double dating; 43 suggested it creates opportunities for cross-carpeting in relationships; 19 alluded to the fact that it leads to inter-locking in relationships while 8 of them said something bothering on its capability of increasing peer pressure to imbibe a particular sex culture. Here, double dating was the most prominent in all the selected schools. Nonetheless, increased pressure to imbibe a particular sex culture and the habit of interlocking in relationships was not reflected in the responses of any of the respondent from FCE.

The last issue in this table is offensive/poor communication. In this issue, 25 of the respondents say it corrupts language and people are increasingly becoming used to offensive communication. 19 respondents opined that it should be blamed for ambiguous expressions common among youths, in that, words are increasingly being connotatively implied and wrongly spelt. 
In summary, the negative influence of romantic/sex related materials exchanged on SNSs on students' sexual behaviour include abnormal sexual behaviour; academic under-performance; emotional cheating; and offensive/poor communication.

\subsection{Presentation and Analysis of Interview-Generated Data (Qualitative Approach)}

Three students who volunteered from each of the three institutions (meaning a total of 9 students) were interviewed separately. This is to enable the researcher generate more genuine responses to reflect reality and complement the survey. However, the same questions, which made up the interview schedule, were put to all of them to guarantee the reliability of the data so generated. The interview details were transcribed, coded, and summarized as seen in the subsequent tables.

The first question in the schedule which was slated to elicit responses bordering on the aspects of sexuality portrayed on SNS which was coded $\mathrm{A}$ has all other sub themes raised and coded into $\mathrm{A}^{1}, \mathrm{~A}^{2}, \mathrm{~A}^{3}$, and $\mathrm{A}^{4}$ (as in interview table 7); and the second question which sought to find out the influence of SNSs on the students' sexual behaviour was given general code $\mathrm{E}$ and other issues under it were coded into $\mathrm{E}^{1}, \mathrm{E}^{2}, \mathrm{E}^{3}, \mathrm{E}^{4}, \mathrm{E}^{5}$, and $\mathrm{E}^{6}$ as presented accordingly in table 8 .

TABLE 7 (Interview): Aspects of Sexuality Portrayed on the SNSs

Theme
\begin{tabular}{|l|l|l|l|l|l|} 
Issues & KSU & FPI & \multicolumn{2}{c|}{ Total } \\
\hline Aspects of Sexuality & 1. Sexual solicitation & 3 & 2 & 3 & 8 \\
Portrayed on SNSs & 2.Exchange of pornographic pictures & 2 & 1 & 1 & 4 \\
& 3. Sex sites & 1 & 0 & 0 & 1 \\
& 4. Sexual enlightenment & 2 & 0 & 0 & 2 \\
\hline
\end{tabular}

\section{Source: Field Work, 2014}

Issues raised by the interviewees on the aspects of sexuality usually portrayed in the SNSs include sexual solicitation in the form of asking someone out for a date and other sexual advances. This was pointed out by the majority of the interviewees (eight out of nine) alluding to different experiences, though. Another issue identified by the interviewees are exchange of pornographic pictures (four out of nine spotted this), sexual enlightenment (two out of nine said this) and Sex sites which was explained by two interviewees apiece from all the selected schools. To interviewees from FPI and FCE, sexual enlightenment is not usually portrayed on the SNSs and none of them said anything close to it. The interviewees also opined that students infrequently exchanged the above contents online.

TABLE 8 (Interview): Influence of SNSs on the Students' Sexual Behaviour

\begin{tabular}{|l|l|l|l|l|l|}
\multicolumn{2}{c}{ Theme } & \multicolumn{1}{c}{ KSU } & FPI & FCE \\
\hline Effects of online Sexual & 1.Better understanding of sex & 2 & 0 & 1 & 3 \\
Contents on Interviewees' & 2. Building of better relationship & 2 & 2 & 2 & 6 \\
Sexual Behaviour & 3. Increases sexual urge & 2 & 2 & 2 & 6 \\
& 4. Increases infidelity in relationship & 3 & 2 & 2 & 8 \\
& 5. Sexual atrocities & 2 & 1 & 1 & 4 \\
\hline
\end{tabular}

\section{Source: Field Work, 2014}

Having known the aspects of sexuality usually portrayed on the SNSs, the researcher probed further to ascertain the possible effects of such sexual related contents on the sexual behaviour of the interviewees. As seen in table 8, the interviewees identified two positive and four negative effects of sexual contents on the SNSs. According to them, such contents enhance their sexual knowledge (three out of nine explained this) and help them to build better and stronger relationship (six out of nine emphasized this). Nevertheless, it was deduced from responses from the majority of the interviewees (eight out of nine) that regular exposure to SNSs and its sexual contents could lead to increase in infidelity among partners in the form of double/multiple dating, sexual adventurism, cheating amongst others. Also, six of them said it increases their sexual urge, as well as sexual atrocities and corruption of good morals which were identified by four of the interviewees. 


\section{Discussion of Findings}

Findings connected to the demographic variables (table 1) of the respondents show that majority of the students were below 25 years old with females slightly dominating the distribution.

\subsection{RO 1: The Aspects of Sexuality Portrayed on Social Networking Sites Among Students of Tertiary Institutions in Kogi State, Nigeria.}

As a prelude to specific findings on the above objective, the researchers sought (in table 1) to know the frequency at which respondents visits these sites and it was established that they do so frequently. Specific findings as to the aspects of sexuality portrayed on the SNSs show (in tables $3 \& 7$ ) that nude/semi nude pictures, pornographic scenes, pornographic sites, and sexually suggestive expressions are more common sexual/sexually related contents often exchanged on SNSs among students of Tertiary Institutions in Kogi State, Nigeria. The finding also indicates that sexually suggestive language and nude/semi nude pictures respectively, dominate the sexual content often exchanged on SNSs. It was also gathered that an overwhelming majority of the students (97\%) separately confirmed the items listed above at different degrees. This perhaps, conforms to the type of sexual content they would have at one time or the other been exposed to on SNSs. Additionally, the interviewees (table 7) variously agreed on the above and added sexual solicitation and sexual enlightenment as part of the sexual contents portrayed/exchanged on the SNSs. This is in consonance with the findings of Asogwa \& Ojih $(2013$, p. 34) that students "are not only aware that there are sexually related practices undertaken in SNS, but they also have good knowledge of how it is done"'.

Therefore, these findings show that students of Tertiary Institutions in Kogi State, Nigeria, are exposured to sexual/sexually related contents on SNSs and do same frequently. This unmistakably also echoes the words of Katherine, (2006) as cited in Longe, et'al (2007, p. 196) that "sexual talk and displays are increasingly frequent and explicit in this mediated world...'.

\subsection{RO 2: Influence of Sexual Contents on Snss on the Sexual Behaviour of Students of Tertiary Institutions in Kogi State, Nigeria.}

Findings in this study have shown that sexual contents of sorts are actually seen on SNSs by students of Tertiary Institutions in Kogi State, Nigeria. With the accessibility (table 2) and exposure level (table 3) of students to sexual contents on the SNSs established, findings on the influence of sexual contents on SNSs on the sexual behaviour of students of tertiary institutions in Kogi State reveal that exposure to these contents influences the students (see table 4) and that the influence is both way- negative and positive. Majority however agreed that the exchange of/exposure to sex related materials on SNSs affects students' sexual behaviour offline as they try to experiment or replicate same in real life. This implies that the nature of students' activities online have a tremendous possibility of generating offline encounters. For example, they (the interviewees, table 8) say it increases sexual urge and infidelity in relationships, results in sexual atrocities and corrupt morals. From the above premise, it can be inferred that the influence of exposure to and/or sharing sexual related contents on the SNSs on students of Tertiary Institutions in Kogi State, Nigeria is both positive and negative. However, findings indicate that its negative impact is more pronounced, more debilitating and far-reaching on their psyche. This finding however contradicts the submission of Tynes (2007) who stated that online socialization through networks like Facebook is more beneficial to the development of young people than they are harmful or dangerous.

Regrettably, a direct consequence of this exposure may be the current spate of flooding on the social media with stories, photos and/or video clips of students' sexual activities on campuses or even outside it. They sometimes video themselves committing the act (sex, romance, rape, etc) where in at times, the video/photo go viral accidentally or even intentionally as the case may be. The interviewees especially were categorical in these wise and this only go a long way to show how far this have permeated the students uses and gratifications of SNSs. 
Further revealing is the fact that most of the interviewees see 'exposure to sexual related contents on SNSs in this generation as a normal thing and therefore, see nothing wrong with it'. This implies that there is a serious level of cultural laxity and moral degeneration among youth so much so that what is negative and seen as such in time past is gradually melting into the sub-consciousness of the 'digital children' as positive or at best, normal.

\section{Conclusions and Recommendations}

A significant finding of this study is that SNSs utilization exerts both positive and negative effects on the sexual behaviour of students though with the negative aspects of it more conspicuous and dominantly influential. They may promote sex education, leisure and pleasure, but varying immoral sexual activities are also promoted thereby polluting the traditional sacredness of sex among the younger generation. The study additionally found out that there are many especially latent influences that shape students' uses and gratifications of SNSs which has a heavy impact on their world-view of sex and other related issues. Today, the easiest way for someone to meet and engage the other for the purpose of sexual abuse, pornography, or prostitution is through Social Networking Sites. This is the complications of the 'digital age,' the confusion of the 'digital natives,' and the concern of the 'uninitiated analogue generation.' Nonetheless, if positively utilized, SNSs could be a veritable tool for positive education and socialization in the ever changing world. Therefore, the study recommends that:

1. The traditional mass media like television, radio, newspaper, film, etc should endeavour to cultivate programmes that will create awareness on the danger of wayward use of social networking tools and discourage same. The belief in the mass media could eventually trigger a transformation. This therefore implies that they must themselves first be a living model.

2. The Nigerian Cyber-Crime Working Group (NCWG) should also implement laws rather than mere passing of bills and erecting warning posters.

3. Religious leaders/bodies as well as parents should also be actively involved in the re-orientation of the members/wards. This they should do regularly and holistically.

4. Researchers should keep up to date with students and young people's social practices, especially as it affects their handling of social platforms in relation to their sexual behaviours. This is necessary to explore the link/boundary between online-offline and offline-online contacts and its sexual propensities/influences. Rather than mere publication of findings, efforts should be concentrated on effective communication of same targeted at achieving behavioral change.

\section{References}

[1] Adebule, S. O. (2012). Moral discipline and academic performance of secondary school students in Ekiti State of Nigeria. Journal of Ireland International Conference on Education.

[2] Ajayi, O. R. (2006). The effects of moral discipline on the academic performance of junior school students in Ekiti State. An unpublished Post Graduate Diploma research project, University of Ado-Ekiti, Ekiti State, Nigeria.

[3] Asogwa, C \& Ojih, E. (2013).Social networking sites as tools for sexual perversion among students ofuniversity of Nigeria, Nsukka. New Media and Mass Communication 9, 27-38. Retrieved from www.iiste.org.

[4] Brown, J (2002). Mass media influences on sexuality. The journal of sex research. Retrieved from: http://www.thefreelibrary.com/Mass+media +influences+on+sexuality.-a087080439.

[5] Dotonu, T. O. (2011). An assessment of the prevalence of sexual immorality among secondary school students in Ido/Osi Local Government Area of Ekiti State. An unpublished B.A.Ed. project, University of Ado-Ekiti, Ekiti State, Nigeria.

[6] Dowdell, E., Burgess, A., \& Flores, J. (2011). Online social networking patterns among adolescents, young adults, and sexual offenders. American Journal of Nursing, Vol. 111, N0 7. Retrieved from http://www.nursingcenter.com/prodev/ce_article.asp?tid=1192594\#P32P 2. 
[7] Grant, I. (2005). Young peoples' relationship with online marketing practices: an intrusion too far? Journal of Marketing Management, 21(5/6), 60723.

[8] Grant, I. \& O'Donohoe, S. (2007). Why young consumers are not open to mobile marketing communications. International Journal of Advertising, 26 (2), 223-46

https://doi.org/10.1080/10803548.2007.11073008

[9] Longe, O., Chiemeke, S., Onifade, O., \& Balogun, F. (2007). Exposure of children and teenagers to internet pornography in south western Nigeria: Concerns, Trends \& Implications. In Journal of Information Technology Impact, Vol. 7, No. 3. Retrieved from: http://jiti.net/v07/jiti.v7n3.195-212.pdf.

[10] McLoughlin. C. \& Burgess (n.d). Texting, Sexting and Social networking among Australian youth and the need for cyber safety education. Retrieved from: http://search.informit.com.au.ezproxyl.canberra.edu.ausearch;res=AEIPT;sear $\quad$ ch=DN=180552

[11] Oblinger D \& Oblinger, J (2005). Educating the net generation. Retrieved from: www.educause.edu/educatingthenetgen/

[12] Ojo .O. \& Fasuba .O. (2005). Adolescent sexuality and family life education in south-western Nigeria: Responses from focus group discussion. Journal of Social Science, 10(2), 111-118.

https://doi.org/10.1080/09718923.2005.11892466

[13] Olufemi .A. \& Olu .I. (2012). An assessment of the prevalence of sexual immorality among Secondary school students in south west Nigeria. Research Journal in Organizational Psychology \& Educational Studies 1(6) 361-365 (ISSN: 2276-8475). Retrieved from www.emergingresource.org.

[14] Safko, L. (2010). The Social Media Bible. New Jersey: John Wiley \& Sons, Inc.

[15] Stefanone, M., Lackaff, D. and Rosen, D. (2010). The relationship between traditional mass media and social media: reality television as a model for social network site behaviour. Journal of Broadcasting \& Electronic Media54 (3). https://doi.org/10.1080/08838151.2010.498851

[16] Tyne, B. (2007). Sacrificing the Educational and Psychosocial Benefits of Online Social Environments. Journal of Adolescent Research Internet Safety. Retrieved 13/11/2010 from http://www.wilkesbeacon.com/news/online-social-networking-benefits-youth-study-says-1.826458. 